\title{
ANTIBACTERIAL ACTIVITY ASSAY OF MANGROVE EXTRACTS AGAINST SALMONELLA TYPHI AND LISTERIA MONOCYTOGENES
}

\section{UJI AKTIVITAS ANTIBAKTERI EKSTRAK MANGROVE TERHADAP SALMONELLA TYPHI DAN LISTERIA MONOCYTOGENES}

\author{
Apon Zaenal Mustopa ${ }^{1 *}$, Rifqiyah Nur Umami ${ }^{1}$, dan Melki ${ }^{2}$ \\ ${ }^{1}$ Research Center for Biotechnology, Indonesian Institute of Sciences, Bogor, Indonesia \\ ${ }^{2}$ Marine Science Department, Faculty of Natural Science, Sriwijaya University, Palembang \\ *Email: azmustopa@yahoo.com
}

\begin{abstract}
ABSTRAK
Aktivitas antibakteri ekstrak tanaman mangrove, Avicennia marina, Sonneratia caseolaris (berasal dari Teluk Payo, Banyuasin, Sumatera Selatan), Ceriops tagal, Rizhopora apiculata, dan Sonneratia alba (berasal dari Sadai, Bangka Selatan) terhadap Salmonella typhi dan Listeria monocytogenes diteliti menggunakan uji disk difusi agar. Ekstraksi dilakukan menggunakan solven organik (metanol, etil asetat dan aseton secara berurutan). Sebagian besar dari ekstrak yang diuji menunjukkan potensi

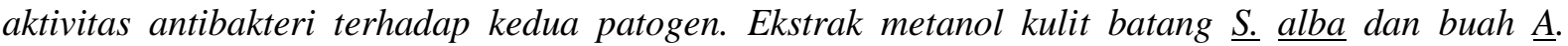
marina menunjukkan zona hambat yang cukup besar $(15 \mathrm{~mm})$ terhadap $\underline{S}$. typhi. Ekstrak aseton daun $S$. alba menunjukkan zona hambat terbesar $(14 \mathrm{~mm})$ ketika diuji terhadap $\underline{L}$. monocytogenes. Purifikasi parsial lebih lanjut dari ekstrak terpilih yang menunjukkan daya hambat besar dilakukan menggunakan kromatografi kolom gel silika dengan berbagai komposisi eluen yang memiliki

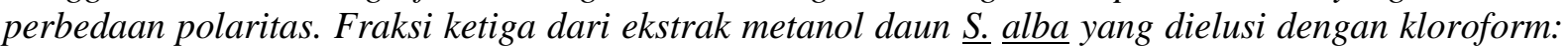
metanol (1:5) menghasilkan zona hambat yang besar $(23 \mathrm{~mm})$ terhadap $\underline{S}$. typhi. Fraksi ketiga dan ketujuh dari ekstrak aseton daun S. alba yang dielusi dengan etil asetat:metanol (7:3) menghasilkan

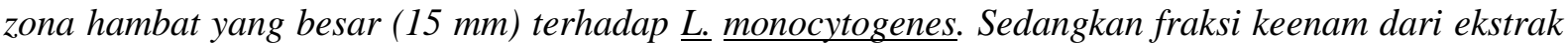
metanol buah A. marina yang dielusi dengan kloroform:metanol (6:4) menghasilkan zona hambat terbesar $(17 \mathrm{~mm})$ terhadap $\underline{L}$. monocytogenes. Hasil ini mengindikasikan bahwa ekstrak mangrove dapat dikembangkan menjadi biomaterial untuk industri biofarmasi maupun biopreservasi.
\end{abstract}

Kata kunci: aktivitas antibakteri, mangrove, kromatografi kolom

\begin{abstract}
The antibacterial activities of mangrove species, Avicennia marina, Sonneratia caseolaris (collected from Teluk Payo, Banyuasin, South Sumatera), Ceriops tagal, Rizhopora apiculata, and Sonneratia alba (collected from Sadai, South Bangka) were screened against Salmonella typhi and Listeria monocytogenes by agar disk diffusion assays. Extractions were conducted using organic solvents (methanol, ethyl acetate, and acetone, subsequently). Most of the extracts tested showed potential antibacterial activity against both pathogens. The methanol extracts of the bark from $S$. alba and the fruit from A. marina showed particularly large inhibition zones $(15 \mathrm{~mm})$ against $S$. typhi. The acetone extract of $S$. alba leaves showed the largest inhibition zone $(14 \mathrm{~mm})$ when tested against $L$. Monocytogenes. Further partial purifications of selected extracts which showed strong inhibition were performed by silica gel column chromatography using various eluent compositions with different polarities. The third fraction of methanol extract from S.alba leaves eluted with chloroform:methanol (1:5) resulted in a remarkably large inhibition zone $(23 \mathrm{~mm})$ against $S$. typhi. The third and seventh fractions of acetone extract from $S$. alba leaves eluted with ethyl acetate:methanol (7:3) resulted in a large inhibition zones $(15 \mathrm{~mm})$ against $L$. monocytogenes. In addition, the sixth fraction of methanol extract from A. marina fruit eluted with chloroform : methanol (6:4) resulted in the largest inhibition zone $(17 \mathrm{~mm})$ against L. monocytogenes. These results indicated that mangrove extracts could be developed as potential biomaterials for biopharmaceutical as well as biopreservation industries.
\end{abstract}

Keywords: antibacterial activity, mangrove, column chromatography 


\section{INTRODUCTION}

Health problems caused by bacterial pathogens derived from food spoilage remains to be a risk factor particularly in developing countries which have sanitation issues. Antibiotics and chemicals are commonly used as therapeutic medicines against bacterial infections. However, maltreatments of antibiotics and chemotherapeutic agents are heading to the new problem of drugs resistance. Thus, the discovery of new and safe antibacterial compounds is continuously needed to work against resistant pathogens.

The widespread use of plants for medication is already known for a long period of time. Plant extracts and phytochemicals have the potentials as alternative treatments against bacterial infections. Indonesia has been blessed with enormous tropial plant species that may represent a source of natural medicines. An interesting group of plants in this regard are mangroves. According to Kusmana (2014), there are approximately 3.2 million hectares of mangrove area in Indonesia with over 202 mangrove species. However, natural medicines derived from mangroves are still inadequately studied due to their limited distribution.

Mangroves are typical plants that live in littoral zone with harsh environmental conditions such as anaerobic soils, wide range of saline concentrations, tidal waves, winds and extreme temperatures. Mangrove plants often produce diverse groups of unique chemical components as secondary metabolites for protection and adaptation in such challenging conditions. Those compounds often have interesting antibacterial, antiviral and antifungal activities. Nevertheless, there are only limited investigations that have been conducted to identify the metabolite agents, which might be responsible for their bioactivities (Bandaranayake, 2002; Eldeen and Effendy, 2013).

In vitro screening for antibacterial activity could be one of the initial steps for the discovery of new antimicrobial agents derived from mangrove extracts. The current study aims to explore the potentials of some selected mangrove species collected from Indonesian mangrove forests, with emphasized to screen their antibacterial activities against two representative foodborne pathogensSalmonella typhi and Listeria monocyogenes.

S. typhi is a Gram-negative bacterium that belongs to the family Enterobacteriaceae. S. typhi infection could lead to the development of typhoid or enteric fever and remains as a threat for public health. Some risk factors such as the oversuse, misuse and inappropriate antibiotics prescribing could be responsible for the increasing number of multi-drug resistance problem among $S$. typhi strains, including ineffective or sub-optimal therapy using ampicillin, chloramphenicol, trimethoprim-sulphamethoxazole, and fluoroquinolones such as ciprofloxacin, and ofloxacin (Zaki and Karande, 2011; Butler, 2011).

L. monocytogenes is a Gram-positive bacterium. L. monocytogenes is a causative agent of listeriosis, however, unlike any other foodborne pathogens, it has the ability to survive food-processing technologies, and could grow even in properly refrigerated food. People usually get infected through the consumption of contaminated food. Although it is a relatively rare infection, L. Monocytogenes is one of the most virulent foodborne pathogens since it could lead to severe infection with up to $30 \%$ fatality rates even with early and adequate antibiotics treatment. The most common clinical manifestation of listeriosis is meningitis, and usually being treated with ampicillin, penicillin or a combination of ampicillin and gentamycin. Other options are trimethoprim-sulfamethoxazole, erythromycin, vancomycin, fluoroquinolones (ciprofloxacin) and quinolones (levofloxacin and moxifloxacin). Some L. monocytogenes isolates were reported to have low resistance to these antibiotics (Allerberger and Wagner, 2010; Hernandez-Milian and Payeras-Cifre, 2014). 


\section{METHODS}

\subsection{Mangrove Plants Collection}

The mangrove plants, Avicennia marina (Forsk.) Vierh., and Sonneratia caseolaris (L.) Engl., were collected from Teluk Payo, Banyuasin, South Sumatera, Indonesia. The locations extend from $02^{\circ} 26^{\prime} 08.6^{\prime \prime}$ to $02^{\circ} 26^{\prime} 12.45^{\prime \prime} \mathrm{S}$ and $104^{\circ} 45^{\prime}$ ' $52 "$ to $104^{\circ} 45^{\prime} 59.9^{\prime \prime} \mathrm{E}$. While Ceriops tagal (Perr.) C. B. Rob., Rizhopora apiculata B1., and Sonneratia alba J.E. Smith, were collected from Sadai, South Bangka, Indonesia, with sampling locations extend from $03^{\circ} 00^{\prime} 02.1^{\prime \prime}$ to $03^{\circ} 00^{\prime} 15.2^{\prime \prime} \mathrm{S}$ and $106^{\circ} 43^{\prime} 45$. 2 " to $106^{\circ} 43^{\prime} 43.2^{\prime \prime} \mathrm{E}$. Information about the environmental conditions including salinity, temperature, $\mathrm{pH}$ and dissolve oxygen (DO) of the locations were recorded. The mangrove samples were taxonomically identified based on their morphological features at Marine Science Department, Faculty of Natural Science, Sriwijaya University, South Sumatera, Indonesia.

\subsection{Mangrove Samples Extraction}

The fresh samples were washed with water to remove dirt and then dried in the oven at $60^{\circ} \mathrm{C}$ for 3 days for leaf samples and up to 7 days for root, bark and fruit samples, respectively. The dried samples were then crushed and powdered into fine particles. Instead of the fresh samples, the dried mangrove plant materials were used since the differences in water content may affect the solubility. The dried samples were ground into fine particles to increase the surface areas, thus will increasing the extraction rates.

The extraction method aims to separate the bioactive compounds of the plant parts from the inactive components using selected solvents. The choice of the solvents for extraction had definite effects for the isolation of bioactive compounds since the solvents will diffuse into the solid plant materials and solubilise the biocompounds with similar polarity during extractions. The longer the contact between solvents and materials the more the bioactive compounds will be extracted. Furthermore, the selected solvents should be less toxic and should not influence the antibacterial assay results (Ncube et al., 2008). Based on the fact that most of the identified bioactive compounds which possess antibacterial activity are commonly less polar or not water soluble, organic solvents (methanol, ethyl acetate and aceton) were used in this study.

The powdered samples were extracted with a series of organic solvents at room temperature according to the standard methods (Joel and Bhimba, 2010; Sahoo et al., 2012) with some modifications. Briefly, to prepare methanol extracts, $100 \mathrm{~g}$ of powdered samples were soaked into $250 \mathrm{~mL} 80 \%$ methanol and stirred. The solvent was subtituted in every 24 hours for 3 days. The total extracts were then filtered through Whatman No.1 filter paper. The filtrate was concentrated using a rotary evaporator at $50^{\circ} \mathrm{C}$ to get crude methanol extracts. To prepare ethyl acetate extracts, methanol extract residues were soaked into $250 \mathrm{~mL} 80 \%$ ethyl acetate and stirred. The solvent was subtituted in every 24 hours for 3 days. The total extracts were then filtered through Whatman No.1 filter paper. The filtrate was concentrated using a rotary evaporator at $40^{\circ} \mathrm{C}$ to get crude ethyl acetate extracts. To prepare acetone extracts, ethyl acetate extract residues were soaked into $250 \mathrm{~mL} 80 \%$ acetone and stirred. The solvent was subtituted in every 24 hours for 3 days. The total extracts were then filtered through Whatman No.1 filter paper. The filtrate was concentrated using a rotary evaporator at $40^{\circ} \mathrm{C}$ to get crude acetone extracts. The extracts were stored at $4^{\circ} \mathrm{C}$ in air-tight glass vials prior to in vitro antibacterial screening.

\subsection{Antibacterial Activity Assay}

Initial screening of potential antibacterial activity or commonly known as antimicrobial susceptibility testing (AST) of the crude mangrove extracts was performed 
against Salmonella typhi (P2KIM collection) and Listeria monocytogenes (BTCCB693) by Kirby-Bauer agar disk diffusion test method (Bauer et al., 1966; CLSI, 2012). The AST method is formerly used as an essential method to determine the microbial resistance to antimicrobials. In this study, the AST method was used as preliminary screening to elucidate the efficacy of antimicrobial candidates derived from mangrove extracts against representative microbial pathogens. The agar diffusion based is the conventional reference method, however, the bactericidal and bacteriostatic effects could not be differentiated using this method.

Briefly, the obtained crude extracts dissolved in the respective solvents $(20 \mu \mathrm{l})$ and positive controls (penicillin or chloramphenicol) were individually applied to the sterilized filter paper disks (Filtres Fioroni ${ }^{\circledR}$, France; $6 \mathrm{~mm}$ in diameter) and then placed on nutrient agar (NA-Oxoid ${ }^{\circledR}$, England) test plates inoculated with the overnight culture of pathogens which had been prepared from the suspension equivalent to $0.5 \mathrm{McF}$ arland turbidity standard $\left(10^{8} \mathrm{CFU} / \mathrm{ml}\right)$. Sterile forceps were used to assure complete contact between the paper disks and the surface of agar medium. The disks were arranged in a proper space to prevent the overlapping of the inhibition zones. The whole set up was first incubated at $4^{\circ} \mathrm{C}$ for 2 hours to give sufficient time for the samples to diffuse into the medium. Then the test plates were kept at $37^{\circ} \mathrm{C}$ for 16,20 , or 24 hours to allow the bacterial growth. The antibacterial activity assays were determined by measuring the diameter of inhibition zones formed around the paper disks.

\subsection{Partial Purification of Bioactive Compound}

Selected crude mangrove extracts which showed strong inhibition zone were applied into a column chromatography packed with silica gel (60-120 Mesh, Merck) based on the method of Mishra and Sree (2007) with some modifications. Each extract was eluted with various selected eluent compotitions initially tested on thin layer chromatography (TLC) according to the method described by Harborne (1984), for optimization of the gradient polarities i.e., chloroform: methanol (1:5); ethyl acetate : methanol (7:3); and chloroform : methanol $(6: 4)$. Individual fractions were then collected and tested for antibacterial activity screening by the same method as described above. Further TLC analysis using silica gel $\mathrm{GF}_{254}$ (Merck) and chloroform: methanol (8:3) as eluent was carried out for the fraction with the strongest antibacterial activity. The TLC results were visualized after heat treatment and under UV light $254 \mathrm{~nm}$.

\section{RESULTS AND DISCUSSIONS}

\subsection{Mangrove Samples Collection and Extraction}

Mangrove plants are generally undervalued and poorly managed. However, numerous mangrove plants had been used in folklore medicine as alternative treatment againts human and animal diseases. In this regard, scientific evidence of their bioactivities are considerably needed. Mangroves are usually need warm condition for survival, thus most of their habitats are in tropical areas. In this study, five species of mangrove plants (i.e., A. marina, C. tagal, R. apiculata, $S$. alba and $S$. caseolaris) were collected from Indonesian mangrove habitats. Different plant parts of the mangrove species (roots, barks, leaves and fruits) were selected as the samples for the screening of antibacterial activity (Figure 1). In addition, the environmental factors such as salinity, temperature, $\mathrm{pH}$, and dissolve oxygen that could affect the bioactive constituents of the samples and leading to the differences in their bioactivities, were recorded (Table 1).

\subsection{Antibacterial Activity Assay}

Food borne pathogens and drug resistance microbes such as $S$. typhi and $L$. monocytogenes remain to be problems 


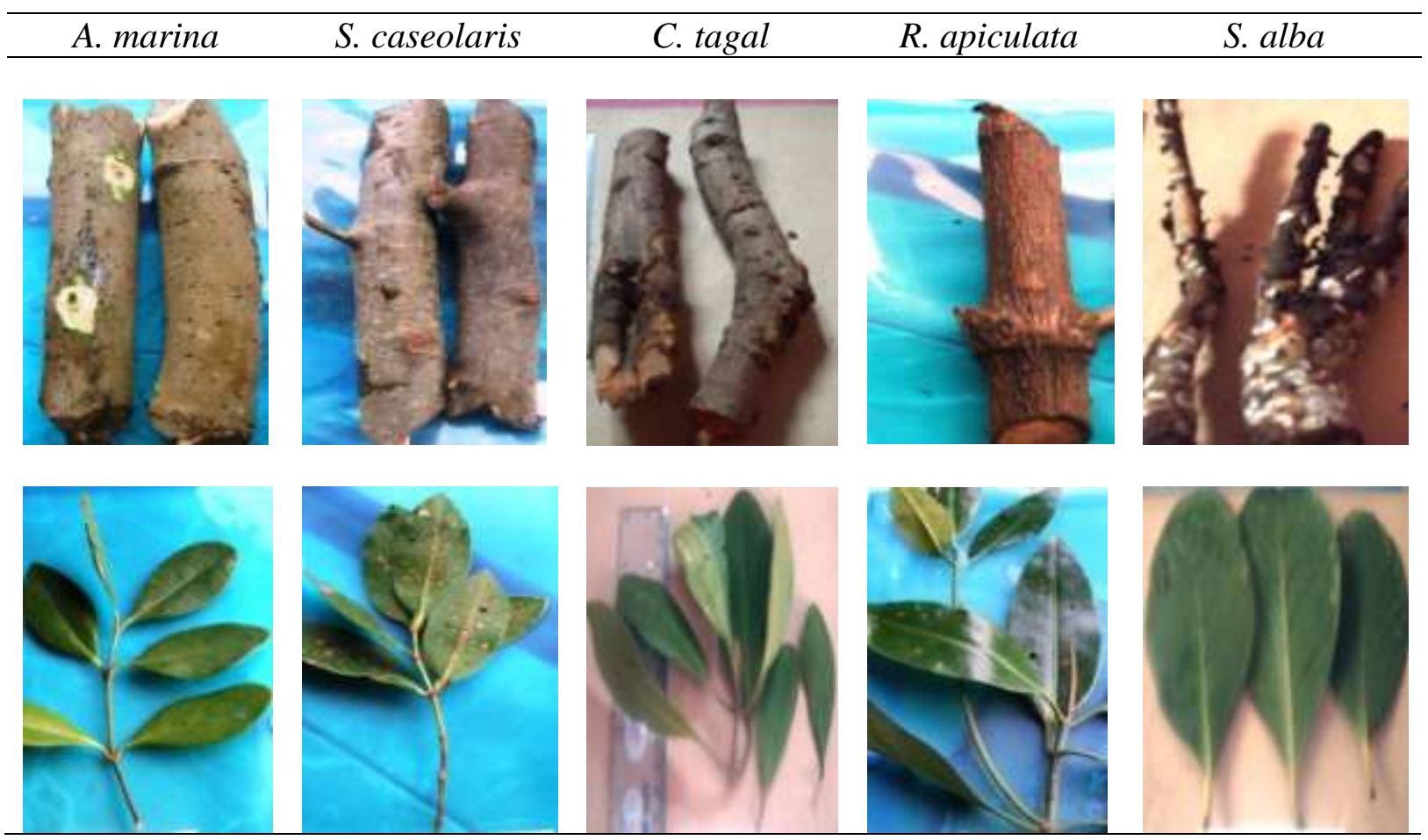

(a)

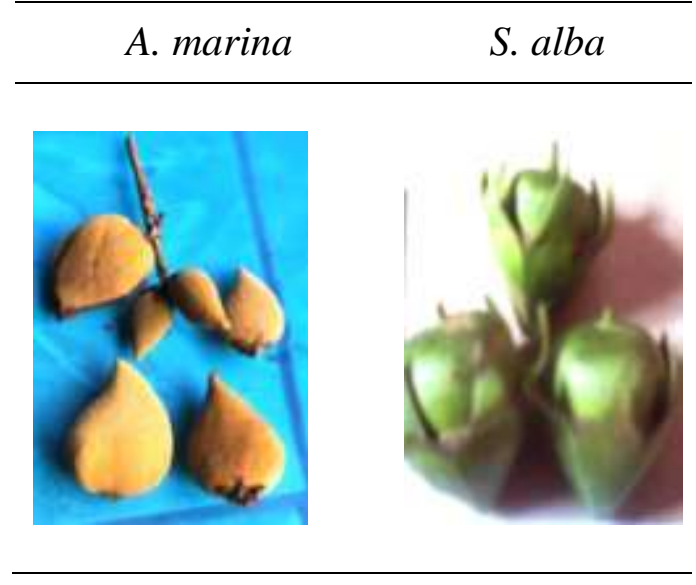

(b)

Figure 1. Photographs of mangrove plants collected in this study (personal collection, 1:10 in scale). Barks and leaves (a), Fruits (b).

Table 1. Environtmental characteristics of mangrove habitat at Teluk Payo, Banyuasin, South Sumatera and Sadai, South Bangka.

\begin{tabular}{crrcrrr}
\hline \multirow{2}{*}{ No } & \multirow{2}{*}{ Parameter } & \multicolumn{3}{c}{ Teluk Payo } & \multicolumn{3}{c}{ Sadai } \\
\cline { 3 - 7 } & & A. marina & S. caseolaris & C. tagal & R. apiculata & S. alba \\
\hline 1 & Salinity $\left({ }^{\circ} / 00\right)$ & 14.00 & 14.00 & 25.00 & 25.00 & 25.00 \\
2 & Temperature $\left({ }^{\circ} \mathrm{C}\right)$ & 31.20 & 34.60 & 30.00 & 29.00 & 30.00 \\
3 & pH & 7.70 & 7.60 & 7.80 & 7.90 & 7.70 \\
4 & DO $(\mathrm{mg} / \mathrm{L})$ & 5.04 & 4.38 & 5.02 & 4.90 & 5.60 \\
\hline
\end{tabular}


among food industries. In the meantime, people are questioning the safety of antibiotics and chemical preservatives. In this study, natural inhibitors for food borne pathogens derived from the extracts of selected mangrove plants were evaluated. This study revealed that the mangrove crude extracts derived from different plant parts and eluted with different solvents show positive antibacterial activities against both of $S$. typhi and L. monocytogenes.

Strong inhibition activities against $S$. typhi were shown by methanol extracts of the bark from $S$. alba and the fruit from $A$. marina (15 $\mathrm{mm}$, respectively), compared to the positive control $(10 \mathrm{~mm})$, after 16 hours observations (Table 2). While acetone extract of the leaves from $S$. alba exhibited particularly large inhibition zone against L. monocytogenes $(14 \mathrm{~mm})$, although it was smaller compared to the positive control $(18 \mathrm{~mm})$, after 24 hours observations (Table 3). This variable results of inhibition zones could be due to the differences of bioactive compounds solubility among the crude extracts.

Previous research articles also provide informations about the biological activities of mangrove extracts. Abeysinghe (2010) reported that some mangroves species had antibacterial activities against antibiotic resistant Staphylococcus aureus. Dhayanithi et al. (2012) reported that methanol extract of the leaves from A. marina could inhibit the growth of $S$. aureus. The silvernanoparticles derived from water extract of the leaves from C. tagal exhibited antimicrobial activity against pathogenic bacteria and fungi (Dhas et al., 2013). According to Pimpliskar et al. (2012), ethanol extract of the stem from $R$. apiculata showed antibacterial as well as antifungal activities. It is reported that ethanol extract of the leaves from $S$. alba could inhibit the growth of $S$. typhi (Sahoo et al., 2012), while methanol extract of the seeds from $S$. caseolaris exhibited growth inhibitory effect against $S$. aureus (Mahadlek et al., 2012). The methanol extract of $S$. caseolaris also reported to have antibacterial activities against multi-drug resistants pathogens by Yompakdee et al. (2012).

\subsection{Partial Purification of Bioactive Compound}

Mangrove species are known as a rich source of bioactive compounds including steroids, triterpenes, phenolics, saponins, flavonoids, alkaloids and tannins (Bandaranayake, 2002). These phytochemicals have toxicological, pharmacological and ecological importance. A knowledge of the chemical constituents of the bioactive compounds derived from natural products is required since it can be great value in discovering new sources of economic phytocompounds particularly in regard of mangrove plants. The phytocompounds could be responsible for the

Table 2. Antibacterial activity of crude mangrove extracts against S. typhi after 16 hours observation.

\begin{tabular}{|c|c|c|c|c|c|c|c|c|c|c|c|c|}
\hline \multirow{3}{*}{ Mangrove } & \multicolumn{12}{|c|}{ Zone of inhibition (mm) } \\
\hline & \multicolumn{4}{|c|}{ methanol extracts } & \multicolumn{4}{|c|}{ ethyl acetate extracts } & \multicolumn{4}{|c|}{ acetone extracts } \\
\hline & root & bark & leaf & fruit & root & bark & leaf & fruit & root & bark & leaf & fruit \\
\hline A. marina & 7 & 7 & 8 & 15 & 8 & 9 & 11 & - & - & - & - & - \\
\hline C. tagal & 9 & 11 & 9 & - & 10 & 14 & 11 & - & - & - & 12 & - \\
\hline R. apiculata & - & 12 & 7 & - & - & 10 & 9 & - & - & - & - & - \\
\hline S. alba & - & 15 & 11 & - & - & 13 & 13 & - & - & - & 13 & - \\
\hline S. caseolaris & - & - & 12 & - & - & - & 11 & - & - & - & - & - \\
\hline
\end{tabular}

Note: (-) : not determined.

Positive control (penicillin) showed $10 \mathrm{~mm}$ of inhibition zone. 
Table 3. Antibacterial activity of crude mangrove extracts against L. monocytogenes after 24 hours observation.

\begin{tabular}{lccccccccccccc}
\hline & \multicolumn{10}{c}{ Zone of inhibition $(\mathrm{mm})$} \\
\cline { 2 - 14 } & \multicolumn{10}{c}{ Methanol extracts } & \multicolumn{1}{c}{ ethyl acetate extracts } & \multicolumn{3}{c}{ acetone extracts } \\
\cline { 2 - 16 } & root & bark & leaf & fruit & root & bark & leaf & fruit & root & bark & leaf & fruit \\
\hline A. marina & - & - & 9 & 12 & - & - & 10 & - & - & - & - & - \\
C. tagal & 10 & 11 & - & - & 10 & 12 & 10 & - & - & - & 13 & - \\
R. apiculata & - & 12 & 11 & - & - & 9 & - & - & - & - & - & - \\
S. alba & - & 13 & - & - & - & 12 & 12 & - & - & - & 14 & - \\
S. caseolaris & - & - & 12 & - & - & - & 13 & - & - & - & - & - \\
\hline
\end{tabular}

Note: (-) : not determined.

Positive control (chloramphenicol) showed $18 \mathrm{~mm}$ of inhibition zone.

antibacterial activities as shown by the mangrove extracts tested in present study. It might be possible that each of the mangrove extracts contain multiple bioactive compounds, and they inhibit bacterial growth in a various ways. Bioactivity guided fractionation using column chromatography was performed as an initial approach to separate the targeting compounds from the mixture within the crude extracts (Joel and Bhimba, 2010).

Some of the obtained fractions showed stonger inhibition activities compared to the crude extracts. The third fraction of methanol extract of the leaves from $S$. alba eluted with chloroform: methanol (1:5) resulted in $23 \mathrm{~mm}$ of inhibition zone against S. typhi after 16 hours observation (Table 4 and Figure 2). While chloramphenicol as positive control also showed $23 \mathrm{~mm}$ of inhibition zone. The third and seventh fractions of acetone extract of the leaves from $S$. alba eluted with ethyl acetate: methanol (7:3) resulted in $15 \mathrm{~mm}$ of inhibition zones against L. monocytogenes. The sixth fraction of methanol extract of the fruit from A. Marina eluted with chloroform: methanol (6:4) resulted in $17 \mathrm{~mm}$ of inhibition zone against L. monocytogenes after 20 hours observation
(Table 5 and Figure 3). While chloramphenicol as positive control showed $20 \mathrm{~mm}$ of inhibition zone. In addition, thin layer chromatography (TLC) analysis of the fraction of $S$. alba which exhibited the largest inhibition zone was performed as initial detection of bioactive compound (Figure 4).

Table 4. Inhibition zone ( $\mathrm{mm}$ ) of column fractions against $S$. typhi after 16 hours observation.

\begin{tabular}{cc}
\hline $\begin{array}{c}\text { Fraction eluted } \\
\text { from column } \\
\text { chromatography }\end{array}$ & $\begin{array}{c}\text { Methanol extract of } \\
\text { S. alba (leaves) } \\
\text { chloroform : } \\
\text { methanol (1:5) }\end{array}$ \\
\hline 1 & 7 \\
2 & 8 \\
3 & 23 \\
4 & 15 \\
5 & 8 \\
6 & 7 \\
7 & 9 \\
8 & 8 \\
9 & 8 \\
10 & 9 \\
Positive control & Chloramphenicol: \\
& 23 \\
\hline
\end{tabular}




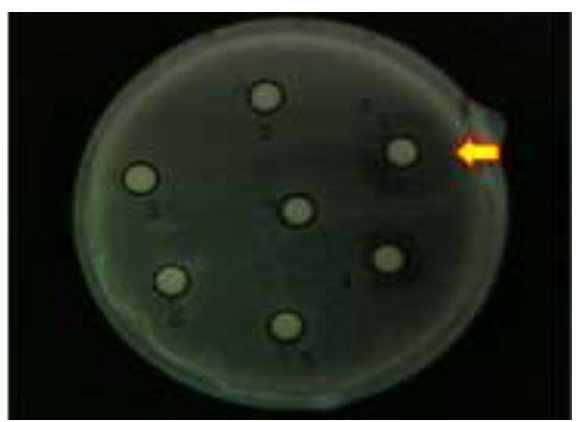

Figure 2. The arrow indicates the inhibition zone of the third fraction of methanol extract of the leaves from $S$. alba eluted with chloroform : methanol (1:5) against $S$. typhi after 16 hours observation.

Table 5. Inhibition zone ( $\mathrm{mm})$ of column fractions against L. monocytogenes after 20 hours observation.

\begin{tabular}{ccc}
\hline $\begin{array}{c}\text { Fraction eluted } \\
\text { from column } \\
\text { chromatography }\end{array}$ & $\begin{array}{c}\text { Acetone extract of S. alba } \\
\text { (leaves) }\end{array}$ & $\begin{array}{c}\text { Methanol extract of A.marina } \\
\text { (fruit) }\end{array}$ \\
\hline 1 & - & $\begin{array}{c}\text { ethyl acetate : methanol (7:3) } \\
\text { chloroform : methanol (6:4) }\end{array}$ \\
2 & - & - \\
3 & 15 & 14 \\
4 & - & - \\
5 & 9 & - \\
6 & - & 17 \\
7 & 15 & 8 \\
8 & - & 10 \\
9 & 7 & 9 \\
10 & 7 & 10 \\
Positive control & Chloramphenicol: 20 & Chloramphenicol: 20 \\
\hline
\end{tabular}

Note: (-) : negative.

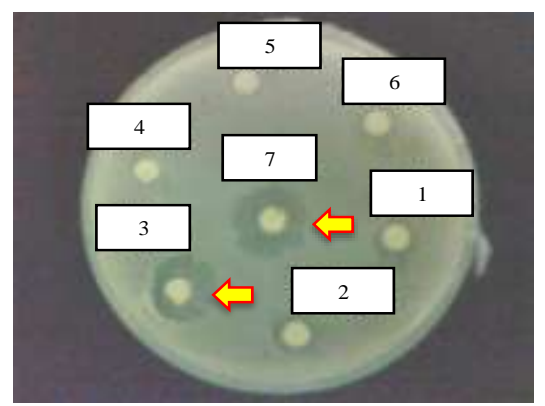

(a)

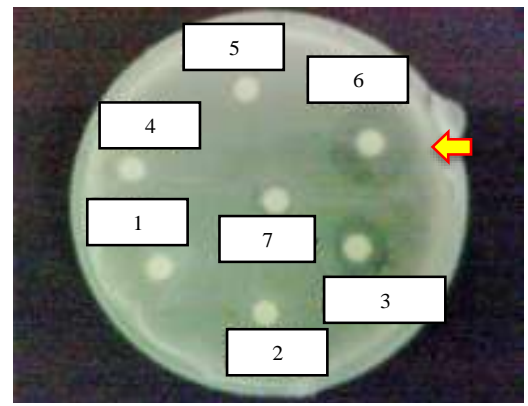

(b)

Figure 3. The arrows indicate the inhibition zone of :

(a). The third and seventh fractions of acetone extract of the leaves from $S$. alba eluted with ethyl acetate : methanol (7:3) against L. monocytogenes after 20 hours observation.

(b). The sixth fraction of methanol extract of the fruit from $A$. Marina eluted with chloroform : methanol (6:4) against L. monocytogenes after 20 hours observation. 


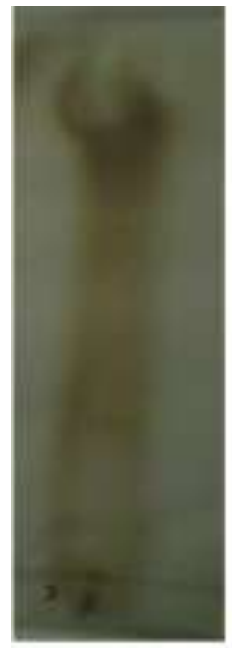

(a)

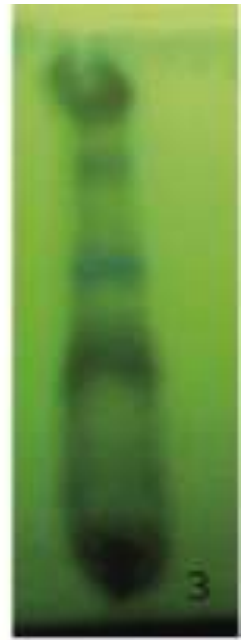

(b)

Figure 4. Thin layer chromatography (TLC) analysis of the third fraction of methanol extract of the leaves from $S$. alba eluted with chloroform : methanol (8:3). Detection after heat treatment (a), detection under UV light $254 \mathrm{~nm}(\mathrm{~b})$.

\section{CONCLUSION}

The crude extracts derived from different parts of the mangrove plants with different solvents exhibited various level of antibacterial activities. The results suggest that the column fractions of mangrove extracts particularly from $S$. alba showed similar antibacterial activity compared to the positive control. This promising findings suggest the presence of bioactive properties against bacterial pathogens as the alternative sources of antibacterial compounds. The mangrove plants, originated from Indonesian areas, have potential to be explored as valuable sources for pharmaceutical applications. However, further elucidation of the compounds responsible for the bioactivities including identification, sufficient isolation and purification, and also the analysis of antibacterial mode of action need to be performed for natural drug development in the future.

\section{AKNOWLEDGEMENTS}

This study was financially supported by BPPS DIKTI 2010 and DIPA LIPI 2011. We thank Muhamad Ridwan, Ika Sari Kusumawati and Dwi Setianingsih for technical assistance. We also thank to reviewers who help to improve this paper.

\section{REFERENCES}

Abeysinghe, P.D. 2010. Antibacterial activity of some medical mangroves against antibiotic resistant pathogenic bacteria. Indian J. Pharm. Sci., 72(2):167172.

Allerberger, F. and M. Wagner. 2010. Listeriosis: a resurgent foodborne infection. Clin. Microbiol. Infect., 16 (1):16-23.

Bandaranayake, W.M. 2002. Bioactivities, bioactive compounds and chemical constituents of mangrove plants. Wetl. Ecol. Manag., 10(6):421-452.

Butler, T. 2011. Treatment of typhoid fever in the 21st century: promises and shortcomings. Clin. Microbiol. Infect., 17(7):959-963.

Bauer, A. W., W. M. Kirby, J. C. Sherris, and M. Turck. 1966. Antibiotic susceptibility testing by a standardized single 
disk method. Am. J. Clin. Pathol., 45(4):493-496.

CLSI. 2012. Performance standards for antimicrobial disk susceptibility tests; approved standard (11 ${ }^{\text {th }}$ Ed). CLSI document M02-A11. Wayne, PA: Clinical and Laboratory Standards Institute. USA. 76p.

Dhas, S.P., A. Mukerjhee, and N. Chandrasekaran. 2013. Phytosynthesis of silver nanoparticles using Ceriops tagal and its antimicrobial potential against human pathogen. Int. J. Pharm. Pharm. Sci., 5(3):349-352.

Dhayanithi, N.B., T.T.A. Kumar, R.G. Murthy and K. Kathiresan. 2012. Isolation of antibacterials from the mangrove, Avicennia marina and their activity against multi drug resistant Staphylococcus aureus. Asian Pac. J. Trop. Biomed., 2(3):S1892-S1895.

Eldeen, I.M.S. and M.A.W. Effendy. 2013. Antimicrobial agents from mangrove plants and their endophytes. In: Vilaz, A.M. (ed.). Microbial pathogens and strategies for combating them: science, technology and education. Formatex Research Center Spain. 2:872-882.

Harborne, J.B. 1984. Phytochemical methods: a guide to modern techniques of plant analysis. $2^{\text {nd }}$ ed. Chapman and Hall Ltd, New York, USA. 43p.

Hernandez-Milian, A. and A. Payeras-Cifre. 2014. What is new in listeriosis? Bio. Med. Res. Int., 2014:358051, 7p.

Joel, E.L. and V. Bhimba. 2010. Isolation and characterization of secondary metabolites from the mangrove plant Rhizopora mucronata. Asian Pac. J. Trop. Med., 3(8):602-604.

Kusmana, C. 2014. Distribution and current status of mangrove forests in Indonesia. In: Hanum I.F., A. Latiff, K.R. Hakeem, and M. Ozturk (eds.).
Mangrove ecosystems of Asia-status, challenges and management strategies. Springer Science \& Business Media. New York. 37-60pp.

Mahadlek, J., T. Phachamud, and C. Wessapun. 2012. Antimicrobial studies of Sonneratia caseolaris using different agar diffusion method. Res. J. Pharm. Biol. Chem. Sci., 3(1):404410.

Mishra, P.M. and A. Sree. 2007. Antibacterial activity and GCMS analysis of the extract of leaves of Finlaysonia obovata (a mangrove plant). Asian $J$. Plant Sci., 6(1):168-172.

Ncube, N.S., A.J. Afolayan, and A. I. Okoh. 2008. Assessment techniques of antimicrobial properties of natural compounds of plant origin: current methods and future trends. Afr $J$. Biotechnol., 7(12):1797-1806.

Pimpliskar, M.R., R.N. Jadhav, and B.L. Jadhav. 2012. Evaluation of antimicrobial principles of Rhizhopora species along Mumbai Coast. $J$. Adv. Sci. Res., 3(3):30-33.

Sahoo, G., N. S. S. Mulla, Z. A. Ansari, and C. Mohandass. 2012. Antibacterial activity of mangrove leaf extracts against human pathogens. Indian J. Pharm. Sci., 74(4):348-351.

Yompakdee, C., S. Thunyaharn, and T Phaechamud. 2012. Bactericidal activity of methanol extracts of crabapple mangrove tree (Sonneratia caseolaris Linn.) against multi-drug resistant pathogens. Indian J. Pharm Sci. 74(3): 230-23.

Zaki, S.A. and S. Karande. 2011. Multi-drug resistant typhoid fever: a review. $J$. Infect. Dev. Ctries, 5(5):324-337.
Diterima
: 17 Juni 2015
Direview
: 23 November 2015
Disetujui
: 27 Desember 2015 